\title{
Flexible Coalitions: Origins and Prospects
}

Permanent Alliances vs Ad Hoc Coalitions

Konstantin V. Bogdanov

\section{Abstract}

The beginning of the 21 st century was marked by the growing popularity of the idea that flexible military-political coalitions built for concrete tactical tasks had certain advantages over long-term strategic alliances. This strategy was actively pursued on the international stage by the George W. Bush administration during its first term (largely owing to Defense Secretary Donald Rumsfeld's efforts) due to mounting contradictions caused by the transformation of the world order and the changing place and role of the United States in it. The U.S. gave up the concept of collective approval for external interference and stepped up unilateral actions. As existing collective security institutions become increasingly plagued with problems, flexible coalition strategies gain more popularity as evidenced not only by U.S. actions but also by those of Russia. While being an important element of the modern world order, which is currently in transition from a unipolar to a multipolar (polycentric) model, the strategy of flexible coalitions has its limits, the most important of which is their destructive impact on the development of

Konstantin V. Bogdanov, Ph.D. (Engineering)

Center for International Security, Primakov National Research Institute of World Economy and International Relations, Russian Academy of Sciences, Moscow, Russia

Research Fellow

ORCID: 0000-0002-5922-0791

SPIN RSCI: 7056-8209

E-mail: cbogdanov@imemo.ru

Address: 23 Profsoyuznaya Str., Moscow 117997, Russia.

DOI: $10.31278 / 1810-6374-2019-17-3-132-150$ 
international relations in the absence of all-encompassing collective security structures (global and/or bloc).

Keywords: U.S. unilateralism, unipolar moment, flexible coalitions, the Rumsfeld Doctrine, alliances in decline, multipolarity, multilateralism

The last fifteen to twenty years have passed amid heated debates on how to transform existing military-political alliances. One of the most popular concepts discussed is flexible coalitions built for the implementation of concrete tasks by allies who may not necessarily be bound by permanent security agreements or deep interdependencies.

The hey-day of this concept is usually associated with U.S. Defense Secretary Donald Rumsfeld (2001-2006), who called for the adaptation of the U.S. foreign policy to the changed environment. However, the transformation of the U.S. military-political strategy, and especially that part of it which deals with coalitions, has proved more complex over the past thirty-five years than just an association with Donald Rumsfeld's name and his role in history. At the same time, the manifesto-like nature of the Rumsfeld Doctrine combined with the rapidly changing global military-political environment in the 2010s once again raise questions about the place of permanent multilateral alliances in the military strategy and foreign policy of the United States in the first place but also of other leading countries and how this role could change in the future. Can there appear a doctrine that will rest on the concept of flexible ad hoc coalitions which are constructive enough to strengthen international stability? Can this experience be used not only in the system of alliances built by the U.S. as a hegemon but elsewhere?

A military-political alliance is understood herein as a group of countries which are permanent (primarily peacetime) members of a military alliance based on the shared understanding of long-term security threats and complemented with a common vision of strategic 
development goals and often (but not necessarily) compatible values and ideologies rooted in the similarity of their sociopolitical and economic systems (institutional approach towards alliances close to the understanding of "historically established" and "natural" alliances as opposed to "tactical" ones, see Ghez, 2011). Major threats may include confrontation with another international actor (bloc) or a permanent diffused threat that requires security cooperation (terrorism, proliferation, international criminal networks, etc.). A flexible coalition is understood to mean a group of countries which is formed for addressing a concrete military-political task and may not necessarily share other frameworks; it is purposefully created for a short period of time and has a rigid and narrow interaction agenda ("project" approach towards alliances, see Silaev, Sushentsov, 2017). These definitions intentionally avoid the format of tactical but longterm coalitions based on broad cooperation, which dominate world history and are created for waging a major war between developed countries. The reason for this is that due to the specific features of the existing international security system, we will be talking here mainly about peacetime relations and a broad network of local conflicts.

The theory of international relations explores the nature, motives and dynamics of alliances (Morgenthau, 1960; Liska, 1962; Osgood, 1968; Holsti, Hopmann and Sullivan, 1973; Waltz, 1979; Walt, 1987; Mearshiemer, 2001) as well as differences between permanent peacetime alliances and tactical wartime coalitions (Snyder, 1990) quite thoroughly and from different angles. Modern researchers' views on changes in the nature and role of coalitions after the disintegration of the bipolar system differ and range from advocating permanent and binding alliances with complex interdependencies (SherwoodRandall, 2006) through a balanced and comprehensive assessment of objective advantages and disadvantages of flexible coalitions and their applicability in different scenarios (Haass, 1997; Cook, 2013) to questioning the benefits of permanent alliances at the current stage (Tertrais, 2004) and even claiming that a transition to flexible ad hoc coalitions is inevitable (Krauthammer, 2004). Russian researchers have also recently made attempts to analyze the reasons for the 
growing popularity of flexible coalitions in the transitional system of international relations (see, for example: Silaev, Sushentsov, 2017; Istomin, 2019).

The advocates of permanent alliances appeal to complex multifactor interdependencies based on a common image of the future and view them as a stabilizing factor (which reduces geopolitical risks) in international relations. The supporters of flexible coalitions say that permanent peacetime alliances are a left-over from the rigid construct and ideological (values) confrontation of the bipolar world and cannot be used effectively anymore (because they would maximize geopolitical advantages).

Opinions about the importance and the future of ad hoc coalitions also differ. For example, Ashton Carter, who eventually became U.S. defense secretary, wrote in 2004 that such alliances could be regarded as "a desperate fallback" (Carter, 2004, p. 74). At the same time, a rather large group of researchers emphasizes radical changes in the nature of military-political alliances after the disintegration of the bipolar system, which drives demand for such coalitions (Tertrais, 2004).

However, in most cases current works focus on the advantages and disadvantages of permanent alliances and flexible coalitions and rarely address systemic issues. At the same time, while analyzing all aspects of flexible coalitions it is necessary to determine their place in the overall dynamics of structural trends, identify the reasons and conditions for their emergence, and assess the nature of their possible impact on the structure of international relations in the long term. A systemic and historical analysis of the evolution of views in the U.S., as a leading global superpower, regarding the formation of alliances, including the planning of external interference, will make it possible to assess the influence of prevailing forms of coalitions on the context of international relations.

\section{TRANSFORMATION OF AMERICAN EXTERNAL INTERFERENCE DOCTRINES IN 1985-2000}

It took the U.S. almost fifteen years to rethink the systemic trauma its military-political planning suffered in Vietnam. It started with 
President Richard Nixon's statement that with all external obligations remaining in effect, the U.S. would in the future require its allies facing a threat to get involved "on the ground" rather than wait for the arrival of American troops (Nixon, 1969). This statement launched the "Vietnamezation" of the conflict in South Vietnam, which ended with the withdrawal of more than 500,000 U.S. troops from the country over a span of four years.

The final turn in the views on interventionism was solidified in 1984 by then Defense Secretary Caspar Weinberger, who used the "all or nothing" principle to formulate the conditions for using American troops outside the country. These conditions included the use of American troops abroad solely for the protection of vital interests and only as a last resort; clear goals and objectives of their use; constant reassessment to make sure that the troops being deployed are enough to achieve these goals and objectives; and sufficient support for the operation from Congress and the general public inside the country (Weinberger, 1984).

These rules were later dovetailed to the coalition strategy by Colin Powell (Chairman of the Joint Chiefs of Staff in 1989-1993). When studying the conditions for U.S. interference not only for protecting vital national interests but also for implementing limited tasks, Powell saw the problem of securing foreign policy support for such operations. This led to a set of views (Weinberger-Powell Doctrine), which not only tightened systemic and purely military requirements for such operations-including the obligatory and clearly-stated exit strategy prior to the interference as well as overwhelming and unlimited military superiority-but also made obligatory broad international support one of the conditions for preparing such operations (Atkinson, 1993; Powell, 1995; Monten, Bennett, 2010).

The George H.W. Bush administration (1988-1992) had developed a solid consensus that major interference outside the unquestionable zone of U.S. influence should be backed by a strong international understanding or at least by the approval of key allies. The model of "a new world order" adopted by the U.S. administration envisaged the predominant use of collective (that is, consensus-based) international 
security mechanisms (Sloan, 1991). While the invasion of Panama in 1989 was unilateral, the operation in Iraq in 1991, carried out by a broad international coalition with the unconditional support of most countries, became a model for the implementation of such a strategy.

However, these views had to be revised more and more often because of radical changes occurring in the system of international relations. In early 1992, the U.S. press obtained draft amendments to the national defense strategy prepared by Deputy Secretary of Defense Paul Wolfowitz, which journalists immediately dubbed "Wolfowitz Doctrine" even though this 46-page document remained just a memorandum. It justified, quite straightforwardly, the U.S.s right for unilateral interference and, most importantly, stressed the archaic nature of big and static military-political alliances which had to give way to tactical ad hoc coalitions under the patronage of the U.S.'s "special stabilizing role" (Tyler, 1992).

This document was disavowed by the George H.W. Bush administration, but the succeeding Clinton administration repeatedly invoked it, for example, by incorporating the principle of "counterproliferation" in military planning documents to justify forcible interventions (including unilateral ones) in order to stop the proliferation of weapons of mass destruction (Aspin, 1993).

The U.S. administration faced both internal and external challenges. The former included, among others, the Congressional power shift to Republicans in the fall of 1994, which made the White House's foreign policy pursuits a constant target for criticism, especially when the Clinton team at first sought cooperative action on the international stage.

External challenges stemmed from the growing gap between the objectives and possibilities of the United States as the only superpower in the "unipolar moment" and immediate practical results that could be obtained through existing alliances and collective security institutions. Radical changes in the external environment and external threats to the U.S. after the disintegration of the bipolar system could not but affect the U.S. approach towards outside interference and international support for it in coalition strategies, placing greater 
emphasis on unilateral actions as a natural response to "tensions" in previous collective structures.

The operation in Bosnia exposed substantial disagreements both among NATO allies and between NATO and the UN (Daalder, 1998). The air campaign against Yugoslavia in the spring of 1989 was carried out solely as NATO's, not UN's, interference, and yet was derisively dubbed "war by committee," thus reflecting the fact that the main battles were fought not in the skies over Belgrade but in the numerous conciliatory committees and working groups. Mismatching objectives and possibilities, on the one hand, and growing disagreements among allies (which had previously closed their ranks against the proSoviet bloc as a common enemy) and in heterogeneous international institutions, on the other hand, naturally pushed Washington towards revising its doctrines.

Eventually, the Clinton administration had to restate its foreign policy strategy to make it "multilateral when we can, unilateral when we must." However, despite all the difficulties and resistance it did its best to seek a broad international consensus (at least a formal one) wherever possible (Patrick, 2010, pp. 24-25). According to A. Bogaturov (1996), it was a period of "pluralistic unipolarity" when the U.S. pursued its leadership not all by itself but taking into account the interests of other G7 countries bound together by common values. Nevertheless the U.S.s deviation from the Weinberger-Powell Doctrine became evident already back then: external interference did not aim to protect vital interests of the country; it was carried out inconsistently and strengthened the interventionist vector in the U.S. foreign policy.

So by the end of the 1990s, there had emerged a set of heterogonous factors in the U.S. that necessitated a revision of George H.W. Bush's legacy and reinforced the unilateral component of the American military-political strategy.

\section{COALITION OBJECTIVES: RISE AND FAILURES OF THE RUMSFELD DOCTRINE}

George W. Bush invited a whole group of right-wing statesmen (neoconservatives)-Dick Cheney, Donald Rumsfeld, Richard Perle, 
and abovementioned Paul Wolfowitz-who held unilateralist and interventionist views to join his team. Condoleezza Rice was not considered a neoconservative and advocated a moderately unilateralist approach. Donald Rumsfeld, who initiated an overhaul of the U.S. military organization to keep it in tune with changing forms of warfare, left a special legacy (Rayburn, Sobchak, 2019, pp. 9-11).

Rumsfeld suggested giving up long preparations for military campaigns with the massing of forces as the Weinberger-Powell Doctrine required. The end of the Cold War changed the nature of "typical" armed conflicts involving the U.S. and increased the need to fight irregular forces, combat terrorism, and use force to prevent the proliferation of weapons of mass destruction. Rumsfeld saw the solution in creating highly mobile units, giving a bigger role to special operations forces, and using high precision weapons from greater distances. Some of the Pentagon's long-term and technologically sophisticated programs, such as the Prompt Global Strike concept, have their roots in this doctrine. Interventions were supposed to be carried out as promptly as possible, without the required massing of forces. An operation had to begin even before all of the assigned forces were deployed, with each unit going into combat immediately upon arrival.

However, the first practical use of the Rumsfeld Doctrine produced controversial results. The operations in Iraq in 1991 and 2003 are usually regarded as the two opposites, which they essentially are in practically all respects: in goals and objectives, in the international preparation of the war, in the speed and scale of prewar deployment, in the balance of forces, and in the way the war was fought in the air and on the ground. Long-term results are no exception. The bulky multinational contingent deployed in 1990-1991 in the Gulf area scored a cheap victory, making rather modest military-strategic gains, but boosted the image of the American military, strengthened alliances, and inspired the nation. However, in 2003 after a rapid deployment another contingent which was only one-third of the previous one needed no more than five weeks to take over Iraq, but it burdened the White House with a long, unpopular and extremely costly guerrilla 
and terrorist war, which on top of it all drove a wedge between the U.S. and Great Britain, on the one hand, and between NATO's leading Western European members, on the other hand (Record, 2007, p. 87).

It is necessary to separate strategy from the immediate interests pursued in a concrete war. There are three aspects to the set of views usually ascribed to Donald Rumsfeld. The first one is the transformation of the U.S. military machine. For this reason alone the new doctrine can be considered a success despite all the failures in Iraq and the tide of criticism against its author. Previous views were rejected as irrelevant to the new nature of warfare: brief but at the same time lowintensity armed conflicts, predominantly contactless war involving the use of high-precision weapons, a multi-factor environment with a tangle of military and non-military aspects, high activity of nonstate actors (from transnational corporations to terrorist groups and private military companies), and faster adoption and implementation of decisions.

The second aspect is the perception of the coalition strategy as part of such warfare. It was described by Donald Rumsfeld in his memo to George W. Bush in September 2001: "The mission determines the coalition, and the coalition does not determine the mission" (Rumsfeld, 2011, p. 354). The call for a wider use of flexible coalitions was quite legitimate as it was necessitated by objective changes in the international situation. However, Rumsfeld acted in his usual manner, resorting to assertive radicalism as he spoke of "old Europe" opposing the war in Iraq, thus multiplying his country's problems within NATO. It must be said that it was the lack of flexibility and attention to political support from allies that prevented the U.S. from building a powerful coalition for the war in Iraq. This could be one of the reasons for its failure (Cook, 2013, p. 563), a failure all the more dramatic because the coalition mechanics plays a key role in the international legitimation of U.S. actions (Istomin, Baykov, 2019). This triggered the collapse of the "pluralistic unipolarity" which was gone completely by the end of the 2000s (Bogaturov, 2008, p. 7).

Finally, the third aspect, which is more noticeable than others but least important in our study, is the development and conclusion of the 
Iraqi campaign, of which Donald Rumsfeld was the driving force and one of the architects (and subsequently its administrative victim) as he sought to apply his views in practice in an aggressive way, using, on the one hand, his hawkish foreign policy views and, on the other hand, administrative tricks and pressure on his subordinates (Dyson, 2009; Rayburn, Sobchak, 2019, pp. 36-38).

As we can see, the George W. Bush administration which pursued the policy of aggressive unilateralism can be criticized for how exactly its foreign policy steps were undertaken on the international stage. The American academic community did this quite thoroughly and convincingly in the 2000s (Ikenberry, 2003; Byman, 2008; Mitchell, Massoud, 2009). But it is hard to question the objective set of problems that guided the White House's actions.

The following conclusions can be drawn from what was stated above:

- After the disintegration of the bipolar system the interventionist component of the U.S. foreign and military policy kept growing under the pressure of circumstances until the beginning of the 2000s when the George W. Bush administration made it a key pillar of its strategy;

- Donald Rumsfeld put this concept together by combining new views on what the U.S. military organization should be like with revised coalition strategies and growing emphasis on unilateralism;

- The war in Iraq and the crisis within NATO can be described as a failure of the George W. Bush administration and a personal fiasco of Donald Rumsfeld as a military-political leader in a fresh crisis he orchestrated himself, but all by themselves they cannot entirely negate the strategy that gives priority to flexible coalitions.

The drawn-out war in Iraq during George W. Bush's second term slightly softened unilateralist tendencies in American interventionism, forcing the administration to look for support abroad (SherwoodRandall, 2006, p. 9). The war in Iraq never became a NATO war even 
though it is hard to overestimate the role the campaign that unfolded simultaneously in Afghanistan played in strengthening the shaken interaction and mutual understanding inside NATO. In fact, NATO transcended its traditional geographical area of responsibility to adopt a global security agenda, thus acquiring new qualities (Morelli, Belkin, 2009, p. 29).

This course was continued by Barack Obama, especially during his first term, when he prioritized the need to improve his country's image abroad, strengthen previous alliances and reorient the U.S. proactive policy from the Middle East to the Asia-Pacific region, which, in turn, required building new alliances and revamping existing ones (Obama, 2007; Hallams, Schreer, 2012, p.319; Unger, 2016).

However, it was then that after the global financial crisis of 2007-2008, NATO's European members started to cut their defense expenditures from $8 \%$ in Germany and Great Britain to $21-36 \%$ in the Baltic states (Mölling, 2012). This was accompanied by fierce burden-sharing debates which reflected the growing disproportion in financial commitments made by the U.S. and other NATO countries (Rasmussen, 2011). These debates also highlighted contradictions within the alliance caused by critical assessments of its efficiency.

Despite a planned increase in NATO defense expenditures after 2014, the situation became worse after the election of Donald Trump who had questioned the alliance's worthiness even before he took office. The new president demanded that the allies increase their defense budgets at least to the agreed $2 \%$ of GDP or better still to $4 \%$ (MacAskill, Crerar, 2018). Trump's attitude towards his allies, which is already creating complications and reminiscent of the situation after the war in Iraq in 2003, clearly reveals attempts to shift the burden of hypothetical containment of Russia in Europe to the latter, thus freeing American resources for carrying out a more flexible policy of interference in other parts of the world.

\section{NEW TIMES AND NEW ALLIANCES}

In the 1990s, faced with a lack of crisis-resolution mechanisms during conflicts with other UN members and with the erosion of the 
"institutional deal" with Cold War-era allies, the U.S. administrations had two options to choose from. They could use time, authority and efforts to overhaul the international security system, which in this case could have obtained (but not necessarily, which was the risk) instruments and potential for ensuring prompt and effective stabilization during crises (Skidmore, 2005). But this would have required the U.S. to give up part of the privileges and possibilities it had received as the de factor winner of the Cold War and would have made any administration daring to take such a step (especially amid confrontation between the executive and legislative branches) vulnerable to internal political infighting. But in the long run this could have helped (with no guarantees, though) create an architecture of equal and equitable international security that would have benefitted all sides. But this scenario never came true.

Instead, the other option was chosen: to step up unilateralist ad hoc efforts, thus delaying the systemic problem of reforming collective security institutions. Essentially, this can be described as a "credit" security model: Washington used its resources and image as well as leading countries' goodwill (among NATO countries as well, as the George W. Bush and Donald Trump experiences prove) to temporarily alleviate current crises, thus leaving all the complications and mounting international tensions for the future administrations to deal with. Repeated discussion paralyses inside permanent coalition structures and international institutions further inspired the U.S. unilateralist policy and destroyed these alliances and institutions, while failing to produce an alternative collective value, except for the American leadership in the system of "imposed consensus." This can be viewed as a paradox of some sort, but the U.S. efforts to preserve its leadership in the "unipolar moment" deformed the system of international relations even more and called American leadership into question, thus laying the ground for the emergence of revisionist powers and a "post-unipolar" world order (regardless of what it will eventually look like).

This makes the transformation of military-political coalitions (not only American ones) inevitable. The crisis of institutions and 
regimes created in the bipolar era gradually led to their collapse (which is especially noticeable in the field of arms control), which, on the one hand, creates a dangerous situation in the world, and on the other hand, increases the need for flexible coalition strategies amid dwindling trust among key players and a shortage of common values.

Meanwhile, the American experience of building flexible coalitions is spreading. The Astana format would be a good example as it has brought together Iran and Turkey with their regional leadership ambitions, an alliance that otherwise would have been unstable in the long term. And yet, it is quite appropriate for addressing concrete issues in the Syria crisis within the framework of a rigid tactical agenda. Another complex and flexible coalition is the post-Soviet "nesting doll" construct made up of the EAEU, the Customs Union, the CSTO, and the Russia-Belarus Union State, with a focus on constant long-term integration, taking into account member countries' differing state of readiness for growing interdependence and coordination in various areas. Its overlapping with the current SCO agenda, including regional security issues, creates an additional dimension.

A somewhat similar construct can be found in American attempts to put new substance into the Quad-quadripartite security dialogue between the U.S., Australia, India, and Japan-which essentially is one of the core institutions for containing China's growing influence (Miller, 2018).

Also noteworthy is the U.S. activities with its allies in Southeast Asia to develop bilateral ties based on an individual agenda, an approach suitable particularly for concrete pairs of allied states. Particularly noticeable against this background is the policy of strengthening relations with former regional partners that were once engaged to contain "world communism" (Tertrais, 2004, p. 138). This work, however, has not always been going smoothly as evidenced by the Philippines' dual policy under President Rodrigo Duterte. The coordinated system of bilateral alliances (both regional and global) may in the future provide the institutional basis for building distributed multilateral flexible coalitions glued together through a major patron power (as some sort of alliance "hub"), which keeps 
the target framework and conducts "shuttle" coordination for solving concrete tasks.

The principles of flexible coalitions, which guided the U.S. war on terror, were further developed in the U.S.-led international coalition against ISIS in Syria and Iraq. It employed a hybrid approach whereby Washington's vigorous efforts to incentivize potential allies were combined with collective work within "umbrella structures," primarily NATO, which promoted mutual understanding and facilitated smoother planning and combat operations. A complex informal coalition built for the war in Libya in 2011 is the previous version of this approach. This was a war waged mainly by NATO's European member states, with the U.S. participation and close coordination with some of the Gulf monarchies which pursued their own militarypolitical interests in the Libyan conflict.

However, the constantly changing context of international relations complicates things. It is generally believed that the "unipolar moment" is temporary, as the author of this concept noted (Krauthammer, 1990), and presumably signifies a transition from a bipolar to a multipolar (polycentric) system. How will this transition affect flexible coalitions which have proved so efficient thus far? Andrei Kortunov (2019) believes that associations with previous multipolar balance of power eras (such as the Concert of Europe) are far-fetched. In the 20th century, the very nature of foreign policy changed, with values and ideology coming to the fore as more grassroots actors joined politics. The pragmatic "dance of coalitions," like that of 18th-19th century European monarchies, becomes less probably due to public pressure in democratic states and the inertia of mass propaganda (especially amid mounting populism in politics and increasingly coordinated activity of social groups in information society). This would also be highly improbable even if one overlooks the dominating U.S. militarystrategic and politico-economic weight, which cannot be evened out by any "multipolarity" and which by far exceeds that of the British Empire in the 19th century or of France in the 18th century.

This makes it necessary to problematize flexible coalitions as well. But what could be a permanent common framework for a group 
of such coalitions glued together either by the patron power or by composition? What are the peculiarities of relations between members of different coalitions, especially if both consider themselves key allies of the patron power? The erosion of permanent collective security institutions at a time when the global hegemon is growing weaker creates an atomized environment, which can easily turn into a new Cold War of all against all, thus wasting resources needed for building flexible coalitions. What gave major players the freedom of maneuver when the previous world order was in crisis may lay a time bomb under the emerging world order. Contrariwise, constructive existence of flexible coalitions will require an all-encompassing superstructure which can only be provided by a consensus-based international security system and/or restoration of the bloc system.

Therefore it would be more realistic to view the passion for flexible coalitions as an important but transient phenomenon inherent to a concrete transitional period. The actualization of this phenomenon, carried out among others by Donald Rumsfeld in the 2000s, gave leading players a convenient and flexible instrument for tactical alleviation of crises, which, however, like the American preoccupation with unilateralism, strategically corrodes the institutional space of international interaction rather than strengthens international security. If the world order is stabilized through a new kind of bipolarity or major renovation of the global collective security system, flexible coalitions will by all means be absorbed by these structures as a specific instrument of limited use.

As one of the constructive transformation scenarios, Andrei Kortunov (2019) names the principle of multilateralism, which takes into account the interests of all members of the collective security system through deeper interdependence and a new level of integration aimed at ensuring equal and equitable security. A similar view of stabilizing alliances reinforced by interdependence was earlier expressed by E. Sherwood-Randall (2006) who had analyzed a narrower problem of correlation between long-term American national security interests and different coalition strategies.

A shared vision of common threats could serve as the basis for common values at the initiate stage, even though there is no doubt that 
this would not be enough for long-term and sustainable existence of such a system. Such a broad framework will most certainly have room for flexible coalitions to solve concrete tasks. A close analogue would be major UN peacekeeping and peace-enforcement operations during the Cold War.

\section{References}

Aspin, L., 1993. Counterproliferation Initiative. Presidential Decision Directive PDD/NSC 18. Available at: <https://fas.org/irp/offdocs/pdd18.htm >. [Accessed 02 April 2019].

Atkinson, R., 1993. Crusade: The Untold Story of the Persian Gulf War. New York: Houghton Mifflin.

Bogaturov, A.D., 1996. Pliuralisticheskaia odnololiarnost' i interesy Rossii' [Pluralistic Multipolarity and Russia’s Interests]. Svobodnaia Mysl' [Free Thought], No. 2, pp. 24-36.

Bogaturov, A.D., 2008. Kontrrevoliutsiia tsennostei i mezhdunarodnaia bezopasnost' [The Counterrevolution of Values and International Security]. Mezhdunarodnye protsessy [International Trends], Vol. 6, No. 2, pp. 4-15.

Byman, D., 2008. An Autopsy of the Iraq Debacle: Policy Failure or Bridge Too Far? Security Studies, Vol. 17, No. 4, pp. 599-643.

Carter, A., 2004. How to Counter WMD. Foreign Affairs, Vol. 83, No. 5, pp. $72-85$.

Cook, J., 2013. Military Alliances in the 21st Century: Still Relevant after All These Years? Orbis, Vol. 57, No. 4, pp. 559-573.

Daalder, I., 1998. Decision to Intervene: How the War in Bosnia Ended. Foreign Service Journal, Vol. 75, No. 12, pp. 24-31.

Dyson, S., 2009. 'Stuff Happens': Donald Rumsfeld and the Iraq War. Foreign Policy Analysis, Vol. 5, No. 4, pp. 327-347.

Ghez, J., 2011. Alliances in the 21st Century: Implications for the US-European partnership. Santa-Monica, CA: RAND Corporation.

Haass, R., 1997. The Reluctant Sheriff: The United States After the Cold War. New York: Council of Foreign Relations.

Hallams, E. and Schreer, B., 2012. Towards a 'Post-American' Alliance? NATO Burden-Sharing after Libya. International Affairs, Vol. 88, No. 2, pp. 313-327. 


\section{Konstantin V. Bogdanov}

Holsti, O. R., Hopmann, P. T., and Sullivan, J. D., 1973. Unity and Disintegration in International Alliances: Comparative Studies. New York: Wiley.

Ikenberry, G.J., 2003. Is American Multilateralism in Decline? Perspectives on Politics, Vol. 1, No. 3, pp. 533-550.

Istomin, I., 2019. The Logic of Counterpoint. Russia in Global Affairs, Vol. 17, No. 2, pp. 8-34.

Istomin, I. and Baykov, A., 2019. Dinamika mezhdunarodnykh al'yansov $\mathrm{v}$ neravnovesnoi mirovoi sisteme [Dynamics of International Alliances in an Unbalanced World Structure]. Mirovaya ekonomika $i$ mezhdunarodnye otnosheniya [World Economy and International Relations], Vol. 63, No. 1, pp. $34-48$.

Kortunov, A.V., 2019. Between Polycentrism and Bipolarity. Russia in Global Affairs, Vol. 17, No. 1, pp. 10-51.

Krauthammer, C., 1990. The Unipolar Moment. Foreign Affairs, Vol. 70, No. 1, pp. 23-33.

Krauthammer, C., 2004. A Farewell to Allies. Time [online]. Available at: <http://content.time.com/time/magazine/article/0,9171,570253,00.html> [Accessed 02 April 2019].

Liska, G., 1962. Nations in Alliance: The Limits of Interdependence. Baltimore: John Hopkins University Press.

MacAskill, E. and Crerar, P., 2018. Donald Trump Tells NATO Allies to Spend $4 \%$ of GDP on Defence. The Guardian. [online] Available at: <https://www. theguardian.com/world/2018/jul/11/donald-trump-tells-nato-allies-to-spend4-of-gdp-on-defence> [Accessed 02 April 2019].

Mearsheimer, J.J., 2001. The Tragedy of Great Power Politics. New York: W.W. Norton.

Miller, J.B., 2018. The Quad: Security Cooperation between the US, Japan, India and Australia. Indo-Pacific Insight Series, Vol. 11. Crawley: Perth US-Asia Centre.

Mitchell, D. and Massoud, T., 2009. Anatomy of Failure: Bush's DecisionMaking Process and the Iraq War. Foreign Policy Analysis, Vol. 5, No. 3, pp. 265-286.

Monten, J. and Bennett, A., 2010. Models of Crisis Decision Making and the 1990-91 Gulf War. Security Studies, Vol. 19, No. 3, pp. 486-520.

Morelli, V. and Belkin, P., 2009. NATO in Afghanistan: A Test of the Transatlantic Alliance. Washington, DC: Congressional Research Service. 
Morgenthau, H.J., 1960. The Purpose of American Politics. New York: Knopf. Mölling, C., 2012. Trends Within the European Union. In: O’Donnel, C.M., ed., 2010. The Implications of Military Spending Cuts for NATO's Largest Members. Washington, DC: Brookings, pp. 6-9.

Nixon, R., 1969. The Great Silent Majority (Vietnamization Speech). [online] American History from Revolution to Reconstruction and Beyond. Available at: <http://www.let.rug.nl/usa/presidents/richard-milhous-nixon/ vietnamization-speech-1969.php> [Accessed 02 April 2019].

Obama, B., 2007. Renewing American Leadership. Foreign Affairs, Vol. 86, No. 4, pp. 2-16.

Osgood, R.E., 1968. Alliances and American Foreign Policy. Baltimore: John Hopkins University Press.

Patrick, S., 2010. 'The Mission Determines the Coalition': The United States and Multilateral Cooperation after 9/11. In: Jones, B., Forman, S. and Gowan, R., eds., 2010. Cooperating for Peace and Security: Evolving Institutions and Arrangements in a Context of Changing U.S. Security Policy. Cambridge: Cambridge University Press, pp. 20-44.

Powell, C., 1995. My American Journey. New York: Random House.

Rasmussen, A.F., 2011. NATO After Libya: The Atlantic Alliance in Austere Times. Foreign Affairs, Vol. 90, No. 4, pp. 2-6.

Rayburn, J. and Sobchak, F., eds., 2019. The U.S. Army in the Iraq War. Volume 1: Invasion - Insurgency - Civil War. 2003-2006. Carlisle Barrack, PA: U.S. Army War College Press.

Record, J., 2007. Back to the Weinberger-Powell Doctrine?'Strategic Studies Quarterly, Vol. 1, No. 1, pp. 79-95.

Rumsfeld, D., 2011. Known and Unknown: A Memoir. New York: Sentinel.

Sherwood-Randall, E., 2006. Alliances and American National Security. Carlisle Barrack, PA: Strategic Studies Institute, U.S. Army War College Press.

Silaev, N. and Sushentsov, A., 2017. Soyuzniki Rossii i geopoliticheskii frontir v Evrazii [Russia’s Allies and the Geopolitical Frontier in Eurasia]. Valdai Papers, No. 66, April 2017.

Skidmore, D., 2005. Understanding the Unilateralist Turn in U.S. Foreign Policy. Foreign Policy Analysis, Vol. 1, No. 2, pp. 207-228.

Sloan, S., 1991. The U.S. Role in a New World Order: Prospects for George Bush's Global Vision. Washington, DC: Congressional Research Service. 
Snyder, G., 1990. Alliance Theory: A Neorealist First Cut. Journal of International Affairs, Vol. 44, No. 1, pp. 103-123.

Tertrais, B., 2004. The Changing Nature of Military Alliances. The Washington Quarterly, Vol. 27, No. 2, pp. 135-150.

Tyler, P., 1992. U.S. Strategy Plan Calls for Insuring No Rivals Develop. The New York Times. [online] Available at: <https://www.nytimes.com/1992/03/08/ world/us-strategy-plan-calls-for-insuring-no-rivals-develop.html> [Accessed 02 April 2019]

Unger, D., 2016. The Foreign Policy Legacy of Barack Obama. The International Spectator, Vol. 51, No. 4, pp. 1-16.

Walt, S.M., 1987. The Origins of Alliances. Ithaca, NY: Cornell University Press. Waltz, K.N., 1979. Theory of International Politics. Reading, MA: AddisonWesley.

Weinberger, C., 1984. The Uses of Military Power. [online] Washington, D.C.: National Press Club. Available at: <http://www.airforcemag.com/ MagazineArchive/Documents/2004/January\%202004/0104keeperfull.pdf> [Accessed 02 April 2019] 